\title{
sciendo
}

DOI 10.2478/sbe-2020-0053

SBE no. 15(3) 2020

\section{MEASURING ECONOMIC DEVELOPMENT AND THE IMPACT OF ECONOMIC GLOBALISATION}

\author{
ROUKANAS SPYROS \\ University of Piraeus, Greece
}

\begin{abstract}
:
The aim of this article is to measure economic development and the impact of economic globalisation under the prism of global political economy. Global political economy is a field of study that has its roots in international relations. The growth of world economic transactions after the collapse of the Bretton Woods system in the 1970s created the need for a new field of study, in order to explain the interdependence between politics and economics on the international level. Global political economy is the field of study that also examines the implications of economic globalisation for national economies and for the global economy. The concept of economic development is broader than economic growth, which is related to GDP growth. The concept of economic globalisation has changed the prospects of economic development for certain developed and developing economies. The main changes of economic globalisation are closely related to the following aspects of national economies: trade, finance, and production. The analysis of this article will reveal the effects of economic globalisation on different aspects of economic development. These aspects are studied under the prism of indexes such as Financial Development Index, openness to trade. Human Development Index, the GINI Index and other inequality indexes. The aftermath of the global economic crisis of 2007-2008 placed at the epicentre the interdependence of national economies and the issue of economic inequalities. The study of the aforementioned indexes will highlight the alterations that have occurred from the manifestation of the global economic crisis until today. The article is focusing on the following countries: China, Germany, Greece, and the United States for the last decade (2009-2019), on the basis of the available data.
\end{abstract}

Key words: Global Political Economy, Economic Development, Indexes, Inequality, Economic Globalisation

\section{Introduction}

The purpose of this article is to study economic development under the prism of economic globalisation. In many countries, the process of economic globalisation took on the following characteristics: a) increased trade; b) improvement of foreign direct investment; c) increased capital flows among countries (Ravenhill, 2017a). The aforementioned changes did not occur simultaneously, as, for example, the increase in capital flows was linked to the liberalisation of national financial markets since the $1980 \mathrm{~s}$. In contrast, international trade increased in the post-war period, although its growth was more pronounced since the 1990s (McGrew, 2018). Economic globalisation also pointed to 
the limited explanatory potential of conventional disciplines, such as economy theory and international relations. Therefore, the need for a more comprehensive explanation of the changes affecting both the domestic, and international economic and political environment, gave rise to the discipline of international political economy. According to John Ravenhill, the discipline of international political economy is defined as follows:

Global political economy is a field of enquiry, a subject matter whose central focus is the interrelationship between public and private power in the allocation of scarce resources. It is not a specific approach or set of approaches to studying this subject matter ... Like other branches of the discipline, GPE seeks to answer the classic questions posed in Harold D. Lasswell's (1936) definition of politics: who gets what, when, and how? This definition explicitly identifies questions of distribution as being central to the study of politics. It also points implicitly to the importance of power-the concept that is at the heart of the study of political science-in determining outcomes. (Ravenhill, 2017b, p. 20)

As we can see from the above definition, the concepts of distribution and power within the international economic environment and among the various actors, are central to the field of IPE. IPE is a means for studying how the process of economic globalisation has affected the process of economic development, as well as how the concepts of distribution, and the power that emanates from distribution at any given time, are determined. This article seeks to discuss certain indicators that are related to the concept of economic development and the effects of economic globalisation during the period 2009-2019. This decade was chosen as the time period for the study, in order to capture the consequences of the global financial crisis of $2007 / 2008$ and present the most recent outlook of the economies under review. The countries under review are the following, based on the latest available World Bank data for the year 2018: the US as the largest economy in the world; China, as the second-largest economy in the world, and a rapidly emerging East Asian economy over the last decades; Germany, as the largest economy in the European Union and the fourth-largest in the world; and Greece, as this makes it possible to interpret the country's prospects within such a wide web of indicators, and thus evaluate its further prospects, especially given the effects of the global and European economic crises on the Greek economy (World Bank, 2019a).

The concept of economic growth, which is narrower than that of economic development, is related to increases in GDP, and represents the total value, at constant prices, of the final goods and services produced in a country within a specified time period, e.g. a year (IMF, 2019a). A concise definition of the concept of economic development, which introduces us to the analysis of the following indicators, is this:

"Economic development: The process through which a country, a region, or the world as a whole advances to a new level of economic performance. It is conventionally usually associated explicitly with growth performance, but there are other measures of development such as happiness, security of the means to a good life, and the fulfilment of human potential." (Ravenhill, 2017b, p. 416).

The article emphasises on the concept of economic development and its effects on the economic inequalities of the countries under review as a result of the process of economic globalisation. The indices that are discussed here, are the following: the Financial Development Index; the openness to trade index; the Human Development Index 
(HDI); the GINI inequality index (GINI Index); and other criteria for measuring economic inequality within a country.

\section{Financial development index and trade openness}

The process of economic globalisation has been linked with the adoption of specific reforms aimed at improving economic growth. The reforms mostly revolve around the following issues: 1) trade liberalisation; 2) establishment of an environment that is more conducive to attracting FDI; 3) privatisation of state-owned enterprises; 4) lifting of capital controls; and 5) fiscal adjustment, aimed at reducing fiscal deficits and public debt levels. For many analysts, the adoption of the aforementioned reforms was tantamount to the adoption of the concept of neoliberalism in economic policy-making. Whenever these reforms were implemented in a dogmatic way, without taking into account the situation prevailing in each country, the empirical findings point to inefficiency as far as the objective of steady economic growth is concerned. For example, as regards the financial opening of an economy, a key parameter is the type of flows this attracts. Attracting portfolio investment and banking flows seems to enhance economic volatility and the possibility of economic crises, in contrast with the attraction of FDI, the flow of which is steadier (Ostry, Loungani and Furceri, 2016). Moreover, in certain cases financial openness is linked to the rise of economic inequalities. The rise of economic inequalities is a factor that undermines economic growth. This article discusses financial openness as a key aspect of economic globalisation, as well as how it contributes to economic development and, by extension, to the increase or decrease of economic inequalities.

The study of financial openness and its effects on economic growth and economic inequalities is performed on the basis of the Financial Development Index of the IMF. This index studies 180 countries from 1980 onwards, the most recent available data being that for 2017. The index, as presented on Table 1, consists of two pillars, each comprising three sub-indices (IMF, 2019b). The Financial Institutions pillar comprises the following indices: 1) the Financial Depth Index; 2) the Financial Access Index; and 3) the Financial Efficiency Index. The same sub-indices are also included in the Financial Markets pillar, which, nonetheless, has a different content.

Tables 2, 3 and 4 show the performance of the countries under review, for the period 2009-2019. The data available for the index refer to the years from 2009 to 2017. First, Table 2 analyses the countries' aggregate performance in terms of the Financial Development Index. As shown by the study, the US is the top performer in all the years under review, with an index of 0.88 for 2017 , and is ranked second in the world, after only Switzerland (IMF, 2019d). The second place is occupied by Germany, which, nonetheless, saw its performance deteriorate from 0.87 in 2009 to 0.69 in 2017. China is ranked third over the past few years, having improved its performance from 0.54 in 2009 to 0.64 in 2017. Greece is ranked last among the countries under review, and, in fact, its performance deteriorated even further, from 0.65 in 2009 to 0.54 in 2017. 


\section{Table 1. Overviews of Financial Development Index}

\begin{tabular}{|c|c|c|c|c|c|}
\hline \multicolumn{6}{|c|}{$\begin{array}{c}\text { Financial Development index (FD) is a relative ranking of countries on the depth, access and efficiency of their financial } \\
\text { institutions and financial markets. } \\
\text { It is an aggregate of the Financial Institutions Index and the Financial Markets Index }\end{array}$} \\
\hline \multicolumn{3}{|c|}{ Financial Institutions index $(\mathrm{FI})$ is an aggregate of } & \multicolumn{3}{|c|}{ Financial Markets Index (FM) is an aggregate of } \\
\hline $\begin{array}{l}\text { Financial Institutions } \\
\text { Depth index (FID) } \\
\text { which compiles data on } \\
\text { bank credit to the } \\
\text { private sector in } \\
\text { percent of GDP, } \\
\text { pension fund assets to } \\
\text { GDP, mutual fund } \\
\text { assets to GDP, and } \\
\text { insurance premiums, } \\
\text { life and non-life to GDP }\end{array}$ & $\begin{array}{c}\text { Financial } \\
\text { Institutions } \\
\text { Access index } \\
\text { (FIA) index } \\
\text { which } \\
\text { compiles data } \\
\text { on bank } \\
\text { branches per } \\
100.000 \\
\text { adults and } \\
\text { ATMS per } \\
100.000 \\
\text { adults }\end{array}$ & $\begin{array}{c}\text { Financial } \\
\text { Institutions } \\
\text { Efficiency } \\
\text { index (FIE) } \\
\text { which } \\
\text { compiles data } \\
\text { on banking } \\
\text { sector net } \\
\text { interest } \\
\text { margin, } \\
\text { lending- } \\
\text { deposits } \\
\text { spread, non- } \\
\text { interest } \\
\text { income to } \\
\text { total income, } \\
\text { overhead } \\
\text { costs to total } \\
\text { assets, return } \\
\text { on assets, } \\
\text { and returns } \\
\text { on equity }\end{array}$ & $\begin{array}{c}\text { Financial } \\
\text { Markets } \\
\text { Depth index } \\
\text { (FMD) which } \\
\text { compiles data } \\
\text { on stock } \\
\text { market } \\
\text { capitalisation } \\
\text { to GDP, } \\
\text { stocks traded } \\
\text { to GDP, } \\
\text { international } \\
\text { debt } \\
\text { securities of } \\
\text { government } \\
\text { to GDP, and } \\
\text { total debt } \\
\text { securities of } \\
\text { financial and } \\
\text { nonfinancial } \\
\text { corporations } \\
\text { to GDP }\end{array}$ & $\begin{array}{c}\text { Financial } \\
\text { Markets } \\
\text { Access index } \\
\text { (FMA) which } \\
\text { compiles data } \\
\text { on percent of } \\
\text { market } \\
\text { capitalisation } \\
\text { outside of top } \\
10 \text { largest } \\
\text { companies } \\
\text { and total } \\
\text { number of } \\
\text { issuers of } \\
\text { debt } \\
\text { (domestic and } \\
\text { external, } \\
\text { nonfinancial, } \\
\text { and financial } \\
\text { corporations } \\
\text { per } 100.000 \\
\text { adults }\end{array}$ & $\begin{array}{c}\text { Financial Markets } \\
\text { Efficiency index } \\
\text { (FME) which compiles } \\
\text { data on stock market } \\
\text { turnover ratio (stocks } \\
\text { traded to } \\
\text { capitalisation) }\end{array}$ \\
\hline
\end{tabular}

Source: (IMF, 2019c)

Table 2. Financial Development Index 2009-2019

\begin{tabular}{|c|c|c|c|c|c|c|c|c|c|c|c|}
\hline Countries & \multicolumn{10}{|c|}{ Years } \\
\cline { 2 - 14 }$y$ & 2009 & 2010 & 2011 & 2012 & 2013 & 2014 & 2015 & 2016 & 2017 & 2018 & 2019 \\
\hline China & 0.54 & 0.54 & 0.54 & 0.56 & 0.57 & 0.60 & 0.63 & 0.65 & 0.64 & - & - \\
\hline Germany & 0.77 & 0.75 & 0.73 & 0.73 & 0.71 & 0.71 & 0.73 & 0.70 & 0.69 & - & - \\
\hline Greece & 0.65 & 0.64 & 0.63 & 0.56 & 0.59 & 0.62 & 0.56 & 0.54 & 0.54 & - & - \\
\hline $\begin{array}{c}\text { United } \\
\text { States }\end{array}$ & 0.87 & 0.87 & 0.86 & 0.87 & 0.87 & 0.88 & 0.89 & 0.88 & 0.88 & - & - \\
\hline
\end{tabular}

Source: (IMF, 2019e)

Table 3 studies the Financial Institutions pillar and compares the performance of each country to its overall performance in the Financial Development Index. As we can see from the financial institutions pillar, the US is the top performer, and its performance has been improving, standing at 0.84 in 2017. Germany comes second, albeit its performance has deteriorated in this case as well, having fallen from 0.76 in 2009 to 0.71 in 2017. China is ranked third among the countries under review as regards this pillar, and its performance has shown a remarkable improvement, from 0.47 in 2009 to 0.63 in 2017 . Finally, Greece presents the opposite picture, since its performance fell from 0.68 in 2009 to 0.57 in 2017.

Table 3. Financial Institutions Index 2009-2019

\begin{tabular}{|c|c|c|c|c|c|c|c|c|c|c|c|c|}
\hline Countries & \multicolumn{10}{|c|}{ Years } \\
\cline { 2 - 14 }$y$ & 2009 & 2010 & 2011 & 2012 & 2013 & 2014 & 2015 & 2016 & 2017 & 2018 & 2019 \\
\hline China & 0.47 & 0.48 & 0.49 & 0.51 & 0.52 & 0.54 & 0.60 & 0.62 & 0.63 & - & - \\
\hline Germany & 0.76 & 0.74 & 0.73 & 0.73 & 0.73 & 0.73 & 0.72 & 0.71 & 0.71 & - & - \\
\hline Greece & 0.68 & 0.68 & 0.66 & 0.66 & 0.65 & 0.59 & 0.58 & 0.57 & 0.57 & - & - \\
\hline $\begin{array}{l}\text { United } \\
\text { States }\end{array}$ & 0.82 & 0.82 & 0.84 & 0.83 & 0.82 & 0.84 & 0.86 & 0.84 & 0.84 & - & - \\
\hline
\end{tabular}


Table 4 discusses the Financial Markets pillar and shows that the US is steadily holding the first place, having the same performance in both 2009 and 2017, i.e. 0.90. Germany is ranked second, its performance having deteriorated, as in the previous tables, from 0.76 in 2009 to 0.65 in 2017 . In contrast, China is ranked third, but has been steadily catching up with Germany, having improved its performance from 0.60 in 2009 to 0.64 in 2017. Greece is the worst performer among the countries under review as regards this pillar, and its performance has been deteriorating, as it fell from 0.60 in 2009 to 0.49 in 2017.

Table 4. Financial Markets Index 2009-2019

\begin{tabular}{|c|c|c|c|c|c|c|c|c|c|c|c|}
\hline \multirow{2}{*}{ Countries } & \multicolumn{11}{|c|}{ Years } \\
\hline & 2009 & 2010 & 2011 & 2012 & 2013 & 2014 & 2015 & 2016 & 2017 & 2018 & 2019 \\
\hline China & 0.60 & 0.59 & 0.58 & 0.60 & 0.60 & 0.65 & 0.65 & 0.67 & 0.64 & - & - \\
\hline Germany & 0.76 & 0.74 & 0.72 & 0.71 & 0.67 & 0.67 & 0.73 & 0.68 & 0.65 & - & - \\
\hline Greece & 0.60 & 0.59 & 0.59 & 0.45 & 0.52 & 0.65 & 0.53 & 0.50 & 0.49 & - & - \\
\hline $\begin{array}{l}\text { United } \\
\text { States }\end{array}$ & 0.90 & 0.91 & 0.87 & 0.90 & 0.90 & 0.90 & 0.90 & 0.90 & 0.90 & - & - \\
\hline
\end{tabular}

Source: (IMF, 2019e)

The Financial Development Index demonstrates the sustained primacy of the US for the period 2009-2019, whereas Germany's performance is deteriorating, China has been improving its position, and Greece's performance is becoming even worse. Another dimension that boosted economic globalisation, apart from financial development, is trade. To this purpose, we will discuss the index that measures the extent of openness to trade. The World Bank defines openness to trade as follows:

"Openness to trade is measured as the trade-to-GDP ratio. It weighs the combined importance of exports and imports of goods and services in an economy, giving an indication of the dependence of domestic producers on foreign demand and of domestic consumers on foreign supply. There is a concave relationship between trade openness and per capita income: as incomes rise, countries tend to trade more, but at a decreasing rate" (World Bank, 2020).

Certain analysts and international organisations point to the positive correlation of economic growth with trade openness (Dabla-Norris et al., 2015, p. 23 and International Monetary Fund, The World Bank and World Trade Organization, 2017, p.8). In order to determine the strength of this argument, Tables 5 and 6 show the performance of the countries under review for the period 2009-2019 in terms of the trade-to-GDP ratio and per capita income. The study of Table 5 reveals that the US economy has the lowest trade-toGDP ratio. Germany's trading volume represents more than $80 \%$ of GDP, followed by China, albeit with a declining ratio, while Greece is ranked third, as the trade-to-GDP ratio has drastically increased from 47.7 percent in 2009 to 72.5 percent in 2018 . The findings of this index point to a mixed picture, as the US, the largest economy worldwide, is less dependent from international trade, whereas Germany, being the fourth largest economy in the world, is highly dependent, with a ratio of more than 80 percent in recent years (Salvatore, 2017 p. 4 and World Bank, 2019a). 
Table 5. Trade (\% of GDP)

\begin{tabular}{|c|c|c|c|c|}
\hline Years & China & Germany & Greece & United States \\
\hline 2009 & 45.1 & 71.2 & 47.7 & 24.6 \\
\hline 2010 & 50.7 & 79.8 & 52.8 & 28.0 \\
\hline 2011 & 50.7 & 85.2 & 57.8 & 30.7 \\
\hline 2012 & 48.2 & 86.5 & 61.8 & 30.5 \\
\hline 2013 & 46.7 & 85.0 & 63.5 & 30.0 \\
\hline 2014 & 45.0 & 84.6 & 67.1 & 29.9 \\
\hline 2015 & 39.6 & 86.1 & 63.0 & 27.7 \\
\hline 2016 & 37.2 & 84.6 & 60.8 & 26.5 \\
\hline 2017 & 38.1 & 87.6 & 67.0 & 27.1 \\
\hline 2018 & 38.2 & 88.6 & 72.5 & 27.5 \\
\hline 2019 & - & - & & \\
\hline
\end{tabular}

Source: (World Bank, 2019b)

Table 6 analyses per capita GDP in current US dollars for the countries under review, during the period 2009-2019. As shown by the analysis of the data, the US has the highest per capita GDP, which is also increasing. Comparing the data of Table 5 we can see that there seems to be no positive correlation between the trade-to-GDP ratio and per capita GDP in the US, as, although per capita GDP continues to rise, trade has been decreasing as a percentage of GDP since 2013. The same stands for China, since trade is reduced as a percentage of GDP, whereas per capita GDP has been growing during the period under review. As regards Germany, the growth of trade as a percentage of GDP seems to be positively correlated with per capita GDP. In the case of Greece, we can see a drop in per capita GDP, along with an increase in the trade-to-GDP ratio, which can be explained by the contraction of the country's GDP as a result of the global economic crisis. In three out of four countries there is no evidence of a positive correlation between GDP growth and trade as a percentage of GDP. Therefore, the growth of trade does not in all cases lead to the reduction of economic inequality, as argued by several economists.

Table 6. GDP per capita (current US\$)

\begin{tabular}{|c|c|c|c|c|}
\hline Years & China & Germany & Greece & United States \\
\hline 2009 & 3.832 & 41.485 & 29.710 & 47.099 \\
\hline 2010 & 4.550 & 41.531 & 26.917 & 48.466 \\
\hline 2011 & 5.618 & 46.644 & 25.916 & 49.883 \\
\hline 2012 & 6.316 & 43.858 & 22.242 & 51.603 \\
\hline 2013 & 7.050 & 46.285 & 21.874 & 53.106 \\
\hline 2014 & 7.651 & 47.959 & 21.760 & 55.032 \\
\hline 2015 & 8.033 & 41.139 & 18.167 & 56.803 \\
\hline 2016 & 8.078 & 42.098 & 18.116 & 57.904 \\
\hline 2017 & 8.759 & 44.240 & 18.883 & 59.927 \\
\hline 2018 & 9.770 & 47.603 & 20.324 & 62.794 \\
\hline 2019 & - & - & - & - \\
\hline
\end{tabular}

Source: (World Bank, 2019c)

In the next section, we will use the Human Development Index, the Gini Index, and other inequality criteria to determine the extent to which financial development and trade openness are positively or negatively correlated with economic development and economic inequalities. 


\section{Human development index - HDI and economic inequalities indexes}

The Human Development Index was first published by the UNDP (United Nations Development Programme) in 1990. From then on, more than 800 reports aimed at promoting human development were produced (UNDP, 2018a). Gradually, the HDI was further developed in order to incorporate various aspects of economic development. Figure 1 shows the evolution of human development-related indices. As shown in Figure 1 the HDI was first published in 1990, the Multidimensional Poverty Index (MPI), the Inequality adjusted Human Development Index (IHDI), and the Gender Inequality Index (GII) were published in 2010, and the Gender Development Index (GDI) was published in 2014. The presentation of these indices shows that, overall, the HDI has undergone significant development during the past 30 years, in order to systematically study different aspects of development, thus providing a more comprehensive picture of the entire process and the measurement of human development.

Figure 1. Evolution of human development composite indices

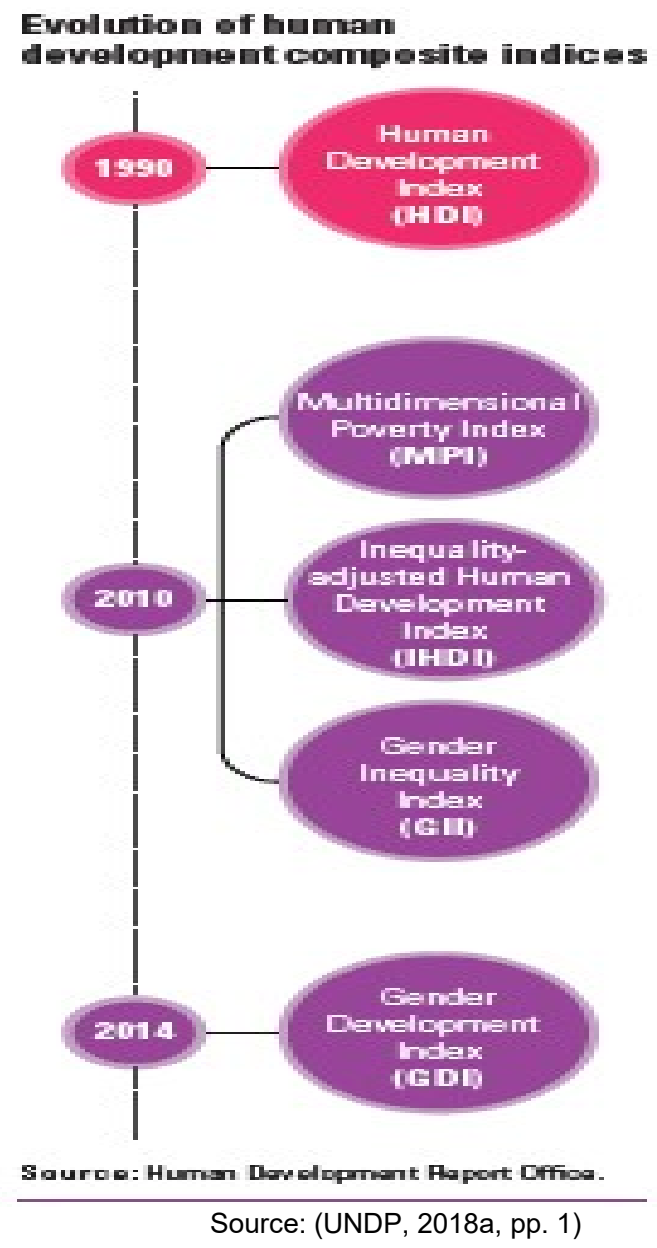


More specifically, according to the UNDP:

"The Human Development Index (HDI) is a composite index focusing on three basic dimensions of human development: the ability to lead a long and healthy life, measured by life expectancy at birth; the ability to acquire knowledge, measured by mean years of schooling and expected years of schooling; and the ability to achieve a decent standard of living, measured by gross national income per capita. To measure human development more comprehensively, the Human Development Report presents four other composite indices. The Inequality-adjusted HDI discounts the HDI according to the extent of inequality. The Gender Development Index compares female and male HDI values. The Gender Inequality Index highlights women's empowerment. And the Multidimensional Poverty Index measures nonincome dimensions of poverty.» (UNDP, 2018a, p. 1)

Figure 2 presents the various dimensions of the Human Development Index. As shown in Figure 2, the first dimension is related to a long and healthy life, and includes life expectancy at birth. Next is the dimension of knowledge, which includes the expected years of schooling and the mean years of schooling. The third dimension refers to a decent standard of living and is related to the gross national income per capita.

Figure 2. The dimensions and indices of the Human Development Index Human Development
Index (HD)

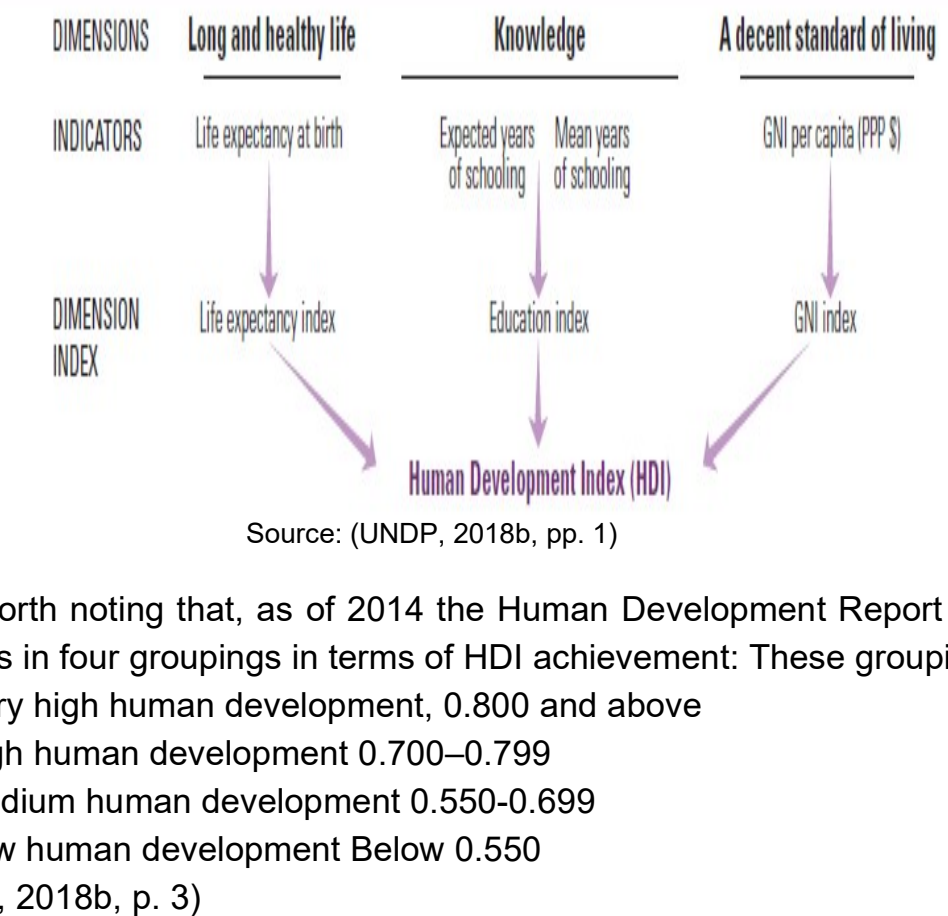
Adecent standard of living

It is also worth noting that, as of 2014 the Human Development Report has been classifying countries in four groupings in terms of HDI achievement: These groupings are:
1) Very high human development, 0.800 and above
2) High human development $0.700-0.799$
3) Medium human development 0.550-0.699
4) Low human development Below 0.550 (UNDP, 2018b, p. 3)

Figure 3 shows the HDI values assigned to various country groupings. We can see that developed countries, i.e. OECD member states, are given the highest values compared with other country groupings, and enjoy very high human development, of more than 0,800 . The global average lies within the high human development range, albeit strongly diverging from the very high human development category. The development of 
the countries of South Asia was very fast during the years under review, whereas SubSaharan Africa, despite exhibiting very slow development in the 1990s, was the fastest growing region on the HDI in the 2000s and 2010s.

Figure 3. Human Development Index values, by country grouping, 1990-2017

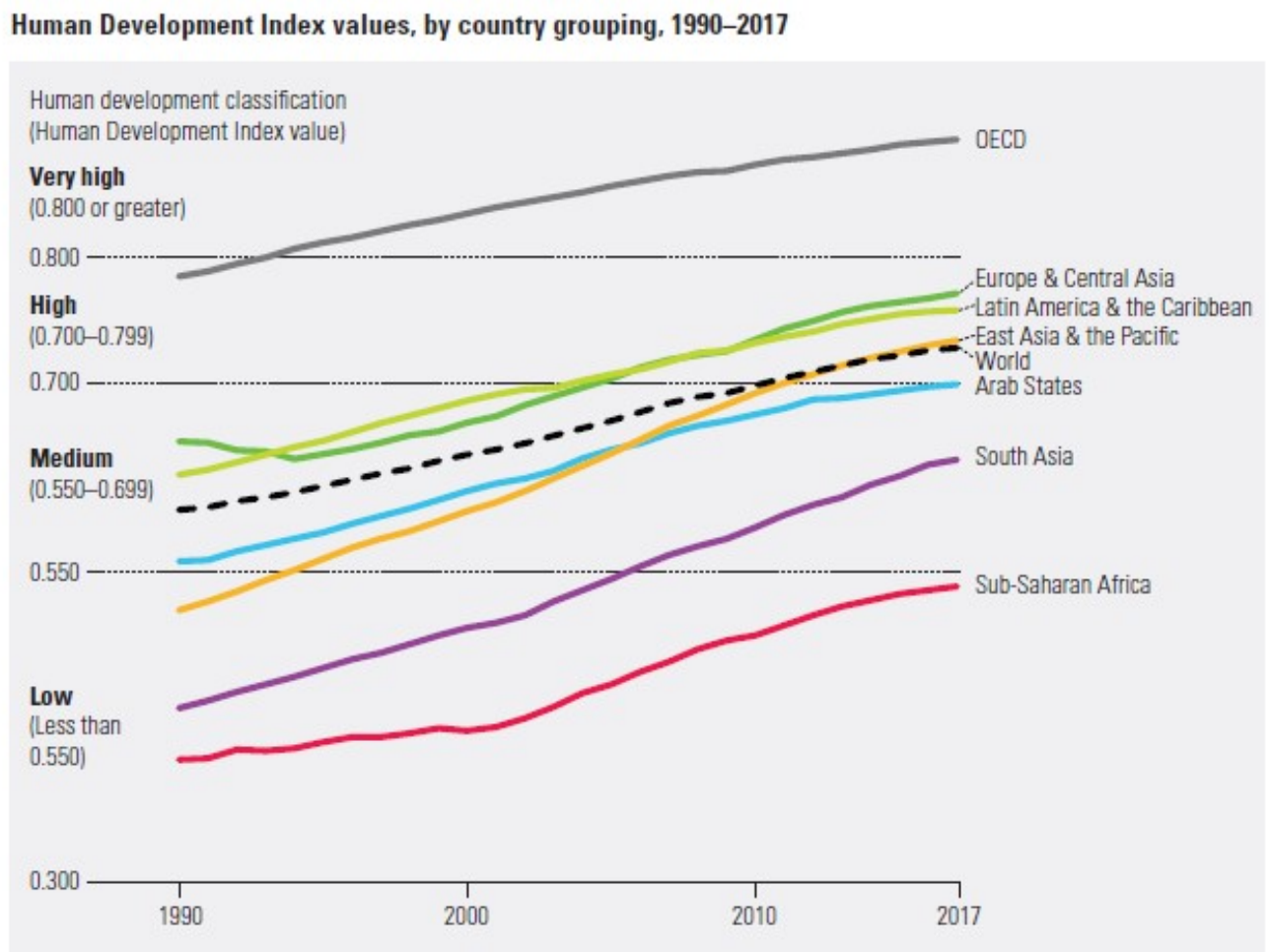

Source: Human Development Heport Offica.

Source: (UNDP, 2018a, pp. 3)

Figure 4 presents arithmetical data, which refer to the situation in the four country groupings in terms of human development, population per grouping, and life expectancy. As shown in Figure 4, life expectancy at birth stands at 79.5 in the very high human development group, and includes 1,439 billion people. In the high human development group, life expectancy stands at 76 years and concerns 2,379 billion people. The medium human development group comprises a population of approximately 2,733 billion, with a life expectancy of 69.1 years. Finally, the low human development group includes 926 million people, with a life expectancy of only 60.8 years. 
Figure 4. Life expectancy at birth, by human development group, 2017 Life expectancy at birth, by human development group, 2017

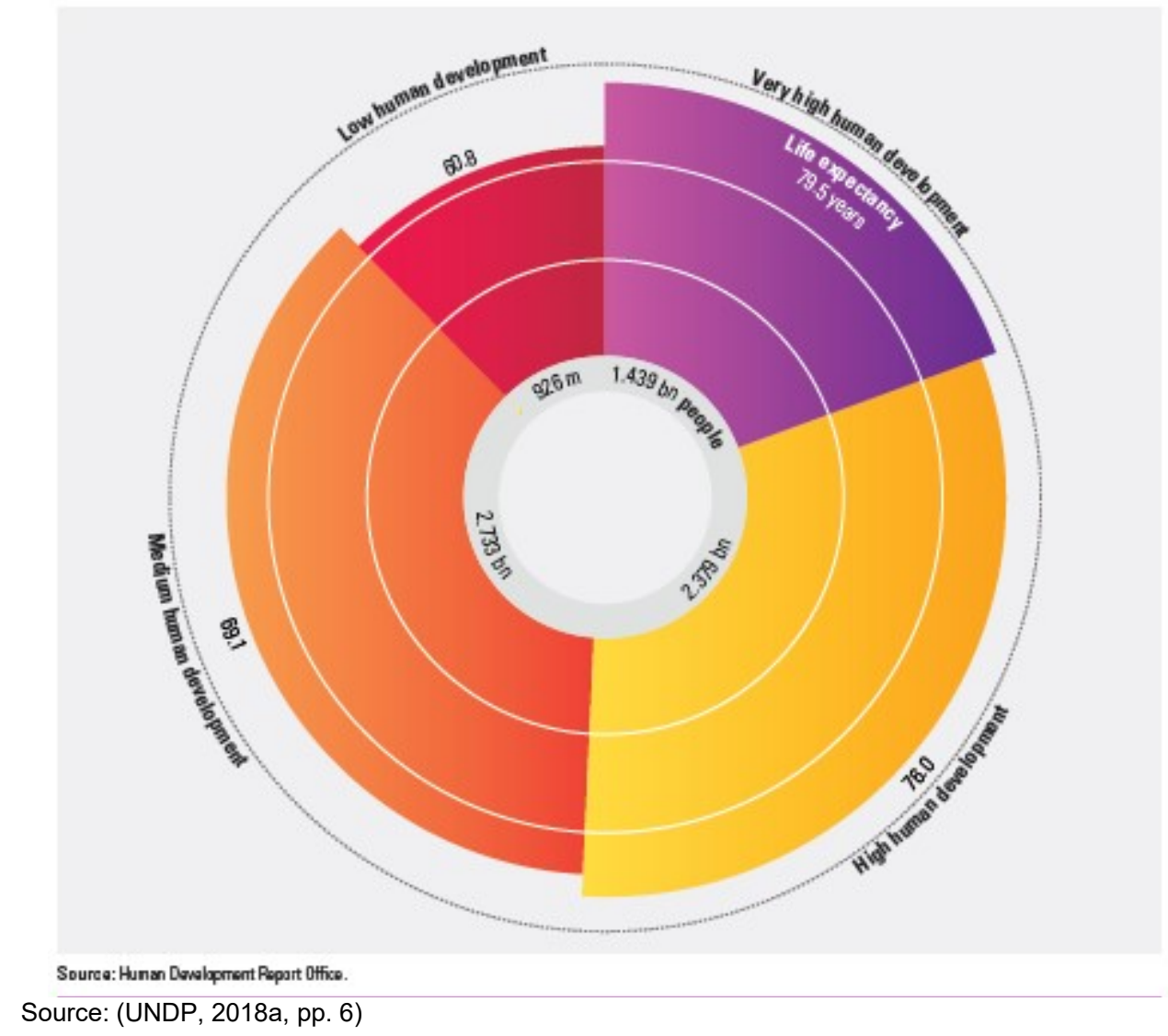

In order to understand the consequences of the global economic crisis, an analysis of the Human Development Index for the countries under review during 2009-2019, was conducted on the basis of the data available. First, Table 7 analyses the case of China. The 2019 statistical update concerns HDI values up to the year 2018 and covers 189 countries and territories recognised by the UN (UNDP, 2019a).

As regards the Inequality-adjusted Human Development Index, the UNDP clarifies that:

"The IHDI combines a country's average achievements in health, education and income with how those achievements are distributed among country's population by "discounting" each dimension's average value according to its level of inequality. Thus, the IHDI is distribution-sensitive average level of human development. Two countries with different distributions of achievements can have the same average HDI value. Under perfect equality the IHDI is equal to the HDI, but falls below the HDI when inequality rises. The difference between the IHDI and HDI is the human development cost of inequality, also termed - the overall loss to human development due to inequality. The IHDI allows a direct link to inequalities in dimensions, it can inform policies towards inequality reduction, and leads to better understanding of inequalities across population and their contribution to the overall human development cost. A recent measure of inequality in the HDI, the 
Coefficient of human inequality, is calculated as an unweighted average of inequality across three dimensions. The IHDI is calculated for 150 countries" (UNDP, 2019b)

Table 8. Inequality-adjusted Human Development Index (IHDI) - China

\begin{tabular}{|c|c|c|c|c|c|c|c|c|}
\hline Years & $\begin{array}{l}\text { Inequality } \\
\text {-adjusted } \\
\text { HDI (IHDI) }\end{array}$ & $\begin{array}{c}\text { Overall } \\
\text { loss in } \\
\text { HDI due } \\
\text { to } \\
\text { inequalit } \\
\text { y }(\%)\end{array}$ & $\begin{array}{l}\text { Coefficient } \\
\text { of human } \\
\text { inequality } \\
(\%)\end{array}$ & $\begin{array}{c}\text { Inequality } \\
\text { in life } \\
\text { expectancy } \\
(\%)\end{array}$ & $\begin{array}{l}\text { Inequality } \\
\text { in } \\
\text { education } \\
(\%)\end{array}$ & $\begin{array}{l}\text { Inequality in } \\
\text { income }(\%)\end{array}$ & $\begin{array}{c}\text { Income } \\
\text { inequality, } \\
\text { Gini } \\
\text { coefficient } \\
2010-2017\end{array}$ & $\begin{array}{c}\text { GINI } \\
\text { index* }\end{array}$ \\
\hline 2009 & - & - & - & - & - & - & \multirow{9}{*}{38.6} & - \\
\hline 2010 & 0,541 & 23.0 & 22.8 & 15.6 & 23.2 & 29.5 & & 43.7 \\
\hline 2011 & 0,552 & 22.3 & 22.1 & 13.5 & 23.2 & 29.5 & & 42.4 \\
\hline 2012 & 0,558 & 22.3 & 22.1 & 13.5 & 23.2 & 29.5 & & 42.2 \\
\hline 2013 & - & - & - & 9.8 & - & 29.5 & & 39.7 \\
\hline 2014 & - & - & - & 9.8 & - & 29.5 & & 39.2 \\
\hline 2015 & - & - & - & 8.9 & - & 29.5 & & 38.6 \\
\hline 2016 & - & - & - & 7.9 & - & 29.5 & & 38.5 \\
\hline 2017 & 0,644 & 14.5 & 14.2 & 7.9 & 11.5 & 23.3 & & - \\
\hline 2018 & 0,636 & 16.1 & 15.6 & 7.9 & 11.7 & 27.4 & & - \\
\hline 2019 & - & - & - & - & - & - & & - \\
\hline
\end{tabular}

" "Gini index measures the extent to which the distribution of income (or, in some cases, consumption expenditure) among individuals or households within an economy deviates from a perfectly equal distribution. A Lorenz curve plots the cumulative percentages of total income received against the cumulative number of recipients, starting with the poorest individual or household. The Gini index measures the area between the Lorenz curve and a hypothetical line of absolute equality, expressed as a percentage of the maximum area under the line. Thus, a Gini index of 0 represents perfect equality, while an index of 100 implies perfect inequality. » (World Bank, 2017a)

Source: (UNDP, 2019a and World Bank, 2019d)

As shown by the analysis of Table 8, in the case of the IHDI performance is lower, as compared with the HDI that was discussed in Table 7. Inequality in income is the main source of inequality, as shown in Table 8, and is higher in China as compared to Germany and Greece, while it has been fluctuating in the US. We can also see a clear decrease in inequality in education from 23.2 in 2010 to 11.7 in 2018, and inequality in life expectancy from 15.6 in 2010 to 7.9 in 2018 . The average loss due to inequality for countries with high human development stands at 17.9, and for the East Asia and Pacific region stands at 16.6. In all the years under review, the overall loss for China due to inequality is more than $10 \%$, while the country outperforms the high human development group, as its performance for the year 2018 was better than in 2010 (UNDP, 2019a). Moreover, the average value of the Gini index for the period 2010-2017 stands at 38.6 and is higher, therefore implies higher inequality, than that of Indonesia (38.1) and Vietnam (35.3).

Table 9. Human Development Index - Germany

\begin{tabular}{|c|c|c|c|c|c|}
\hline Years & $\begin{array}{c}\text { Life } \\
\text { expectancy } \\
\text { at birth } \\
\text { (years) }\end{array}$ & $\begin{array}{c}\text { Expected years } \\
\text { of schooling } \\
\text { (years) }\end{array}$ & $\begin{array}{c}\text { Mean years of } \\
\text { schooling } \\
\text { (years) }\end{array}$ & $\begin{array}{c}\text { Gross national } \\
\text { income (GNI) } \\
\text { per capita } \\
\text { (2011 PPP \$) }\end{array}$ & $\begin{array}{c}\text { Human } \\
\text { Development } \\
\text { Index (HDI) }\end{array}$ \\
\hline 2009 & 80.0 & 16.7 & 13.7 & 39673 & 0,916 \\
\hline 2010 & 80.1 & 16.8 & 13.8 & 41236 & 0,920 \\
\hline 2011 & 80.3 & 16.9 & 13.8 & 43770 & 0,925 \\
\hline 2012 & 80.4 & 16.9 & 13.9 & 43827 & 0,927 \\
\hline 2013 & 80.5 & 16.8 & 13.9 & 43888 & 0,927 \\
\hline 2014 & 80.6 & 16.9 & 14.0 & 44259 & 0,930 \\
\hline 2015 & 80.8 & 17.0 & 14.1 & 45012 & 0,933 \\
\hline 2016 & 80.9 & 17.1 & 14.1 & 45557 & 0,936 \\
\hline 2017 & 81.0 & 17.1 & 14.1 & 46438 & 0,938 \\
\hline 2018 & 81.2 & 17.1 & 14.1 & 46946 & 0,939 \\
\hline 2019 & - & - & - & - & - \\
\hline
\end{tabular}

Source: (UNDP, 2019c) 
In 2018, Germany had a HDI value of 0,939 and, understandably, belongs to the very high human development group. Germany is ranked fourth in the world for the year 2018. Based on its performance, the country is classified in the same group in all the years under review. Germany's performance for the year 2018 stands at 0,939, higher than the average for the very high human development group $(0,892)$, and also higher than the average for the OECD $(0,895)$ (UNDP, 2019c). All HDI components improved during the years under review. We can see a year-on-year decrease in per capital GNI in 2009, which is attributed to the consequences of the global economic crisis of 2007-2008. Figure 6 presents the evolution of $\mathrm{HDI}$ components over time. We can see that education showed rapid progress in order to catch up with the other components of the index, also contributing to HDI performance.

Figure 6. Trends in Germany's HDI component indices 1990-2018

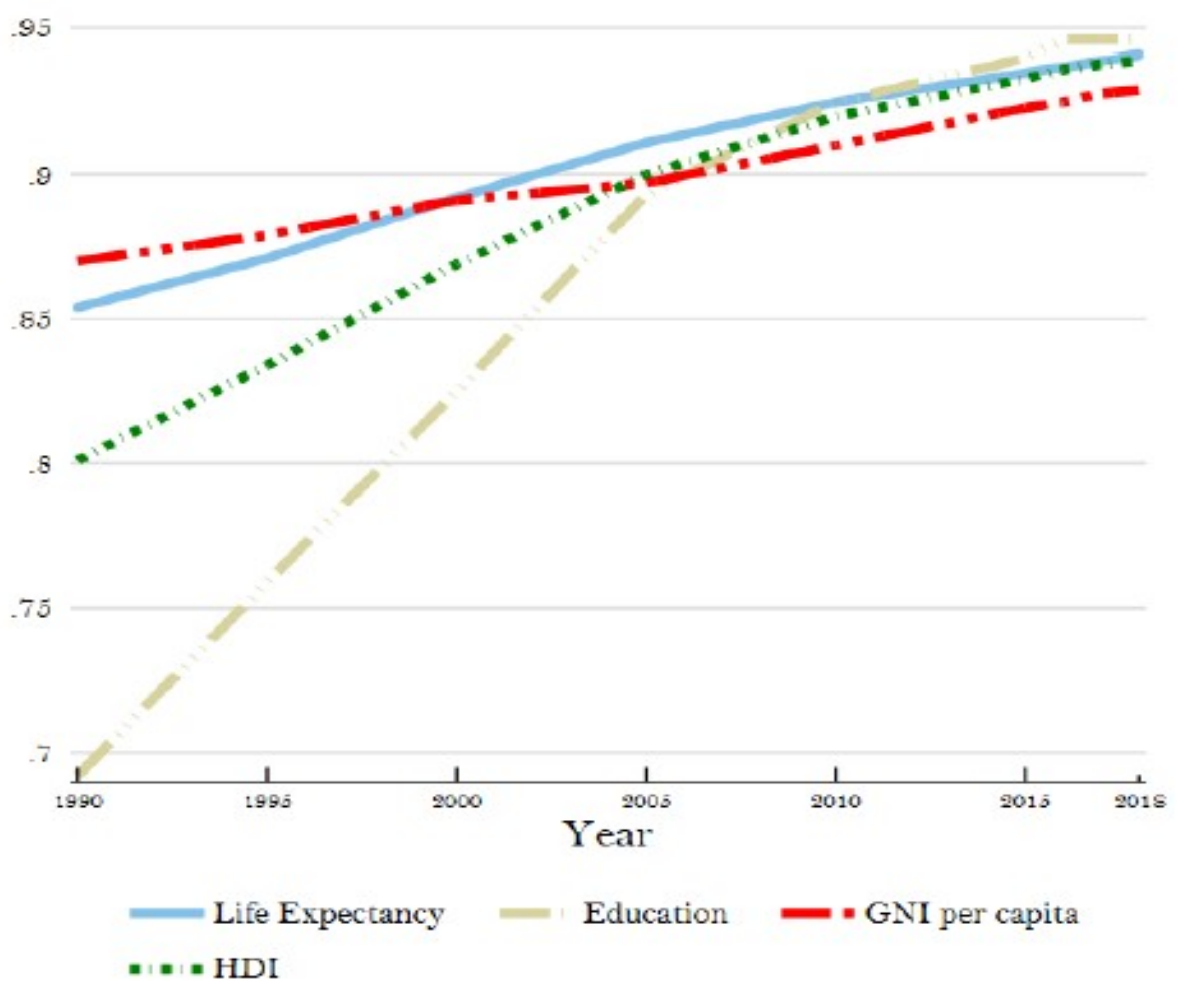

Source: (UNDP, 2019c)

As shown by the analysis of Table 10, in the case of the IHDI performance is lower, as compared with the HDI that was discussed in Table 9. As shown in Table 10, inequality in income is the main source of inequality, as compared to other areas of inequality. The average loss due to inequality for countries with very high human development stands at 10.7, and for OECD countries stands at 11.7. In all the years under review, the overall loss for Germany due to inequality is less than $10 \%$, while the country outperforms all countries of the very high human development group (UNDP, 2019c). Moreover, the average value of the Gini index for the period 2010-2017 stands at 31.7 and 
is lower than in France (32.7) and the United Kingdom (33.2), thus suggesting less inequality.

Table 10. Inequality-adjusted Human Development Index (IHDI)- Germany

\begin{tabular}{|c|c|c|c|c|c|c|c|c|}
\hline Years & $\begin{array}{l}\text { Inequality } \\
\text {-adjusted } \\
\text { HDI (IHDI) }\end{array}$ & $\begin{array}{c}\text { Overall } \\
\text { loss in } \\
\text { HDI due } \\
\text { to } \\
\text { inequality } \\
(\%)\end{array}$ & $\begin{array}{c}\text { Coefficient } \\
\text { of human } \\
\text { inequality } \\
(\%)\end{array}$ & $\begin{array}{l}\text { Inequality } \\
\text { in life } \\
\text { expectanc } \\
\text { y (\%) }\end{array}$ & $\begin{array}{c}\text { Inequality in } \\
\text { education } \\
(\%)\end{array}$ & $\begin{array}{l}\text { Inequality in } \\
\text { income (\%) }\end{array}$ & $\begin{array}{c}\text { Income } \\
\text { inequality, } \\
\text { Gini } \\
\text { coefficient } \\
2010-2017\end{array}$ & GINI index* \\
\hline 2009 & - & - & - & - & - & - & \multirow{9}{*}{31.7} & 30.5 \\
\hline 2010 & 0,846 & 8.0 & 7.8 & 4.4 & 2.3 & 16.7 & & 30.2 \\
\hline 2011 & 0,861 & 6.9 & 6.8 & 4.0 & 1.8 & 14.5 & & 30.5 \\
\hline 2012 & 0,863 & 6.9 & 6.8 & 4.0 & 1.8 & 14.5 & & - \\
\hline 2013 & 0,861 & 7.1 & 7.0 & 3.7 & 2.4 & 14.8 & & 31.1 \\
\hline 2014 & 0,866 & 6.9 & 6.7 & 3.7 & 2.4 & 14.1 & & - \\
\hline 2015 & 0,866 & 7.2 & 7.0 & 3.7 & 2.6 & 14.8 & & 31.7 \\
\hline 2016 & 0,855 & 8.6 & 8.3 & 3.0 & 2.6 & 19.3 & & 31.9 \\
\hline 2017 & 0,862 & 8.1 & 7.8 & 3.0 & 2.7 & 17.7 & & - \\
\hline 2018 & 0,861 & 8.3 & 8.1 & 3.8 & 2.7 & 17.7 & & - \\
\hline 2019 & - & - & - & - & - & - & & - \\
\hline
\end{tabular}

Source: (UNDP, 2019c and World Bank, 2019d)

Table 11. Human Development Index - Greece

\begin{tabular}{|c|c|c|c|c|c|}
\hline Years & $\begin{array}{c}\text { Life } \\
\text { expectancy } \\
\text { at birth } \\
\text { (years) }\end{array}$ & $\begin{array}{c}\text { Expected } \\
\text { years of } \\
\text { schooling } \\
\text { (years) }\end{array}$ & $\begin{array}{c}\text { Mean } \\
\text { years of } \\
\text { schooling } \\
\text { (years) }\end{array}$ & $\begin{array}{c}\text { Gross } \\
\text { national } \\
\text { income } \\
\text { (GNI) per } \\
\text { capita } \\
\text { (2011 PPP } \\
\text { \$) }\end{array}$ & $\begin{array}{c}\text { Human } \\
\text { Development } \\
\text { Index (HDI) }\end{array}$ \\
\hline 2009 & 80.3 & 16.4 & 10.1 & 29749 & 0,859 \\
\hline 2010 & 80.5 & 16.2 & 10.3 & 28134 & 0,857 \\
\hline 2011 & 80.8 & 16.3 & 10.3 & 25428 & 0,853 \\
\hline 2012 & 81.0 & 16.6 & 10.3 & 24521 & 0,856 \\
\hline 2013 & 81.2 & 16.7 & 10.4 & 23714 & 0,858 \\
\hline 2014 & 81.4 & 17.3 & 10.5 & 24242 & 0,866 \\
\hline 2015 & 81.5 & 17.3 & 10.6 & 24165 & 0,868 \\
\hline 2016 & 81.7 & 17.3 & 10.3 & 24187 & 0,866 \\
\hline 2017 & 81.9 & 17.3 & 10.5 & 24647 & 0,871 \\
\hline 2018 & 82.1 & 17.3 & 10.5 & 24909 & 0,872 \\
\hline 2019 & - & - & - & - & - \\
\hline
\end{tabular}

Source: UNDP, 2019d.

Greece's HDI value stood at 0,872 in 2018 , and the country was ranked at the 32nd place, as shown in Table 11. The study of its components reveals an improvement in all categories, with the exception of per capita GNI, given that the decrease in incomes between 2009 and 2013. In 2014 the GNI started growing again, albeit diverging from the disposable income for the year 2009. Overall HDI performance has been fluctuating, but the performance for 2018 is better than that for 2009. Greece's performance for the year 2018 stands at 0,872 , lower than the average for the very high human development group $(0,892)$, as well as the average for the OECD $(0,895)$ (UNDP, 2019d). 
Figure 7. Trends in Greece's HDI component indices 1990-2018

1

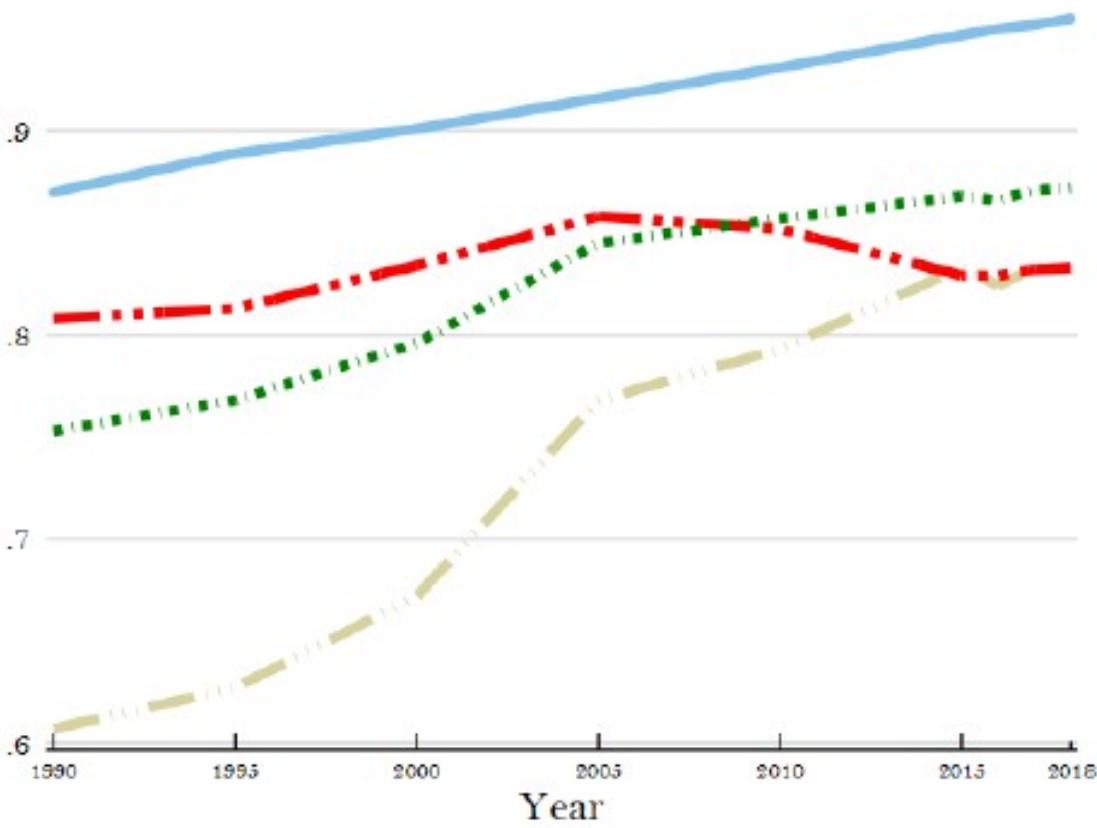

Life Expectancy $=$ Education = - GNI per capita

$\because=$ HDI

Source: (UNDP, 2019d)

Figure 7 captures the evolution of HDI component indices in Greece, since its inception and to this day. We can see that the life expectancy component shows the highest performance, outperforming that of other national economies. Performance as regards education, as well as the overall index, has been improving. In contrast, the per capita gross national income component has been declining, owing to the effects of the global economic crisis of 2007-2008.

Table 12. Inequality-adjusted Human Development Index (IHDI) - Greece

\begin{tabular}{|c|c|c|c|c|c|c|c|c|}
\hline Years & $\begin{array}{c}\text { Inequalit } \\
\text { y- } \\
\text { adjusted } \\
\text { HDI } \\
\text { (IHDI) }\end{array}$ & $\begin{array}{l}\text { Overall } \\
\text { loss in } \\
\text { HDI due } \\
\text { to } \\
\text { inequalit } \\
\text { y (\%) }\end{array}$ & $\begin{array}{c}\text { Coefficien } \\
t \text { of } \\
\text { human } \\
\text { inequality } \\
(\%\end{array}$ & $\begin{array}{l}\text { Inequality } \\
\text { in life } \\
\text { expectanc } \\
\text { y (\%) }\end{array}$ & $\begin{array}{l}\text { Inequality } \\
\text { in } \\
\text { education } \\
\text { (\% }\end{array}$ & $\begin{array}{l}\text { Inequ } \\
\text { ality in } \\
\text { incom } \\
\text { e (\%) }\end{array}$ & $\begin{array}{c}\text { Income } \\
\text { inequal } \\
\text { ity, } \\
\text { Gini } \\
\text { coeffici } \\
\text { ent } \\
2010- \\
2017\end{array}$ & $\begin{array}{c}\text { GINI } \\
\text { index }\end{array}$ \\
\hline 2009 & - & - & - & - & - & - & \multirow{7}{*}{36.0} & 33.6 \\
\hline 2010 & 0,770 & 10.2 & 9.9 & 4.0 & 5.8 & 19.9 & & 34.1 \\
\hline 2011 & 0,749 & 12.2 & 12.1 & 4.8 & 14.3 & 17.1 & & 34.8 \\
\hline 2012 & 0,757 & 11.6 & 11.4 & 4.8 & 11.3 & 18.1 & & 36.3 \\
\hline 2013 & 0,767 & 10.6 & 10.5 & 4.0 & 11.3 & 16.2 & & 36.1 \\
\hline 2014 & 0,760 & 12.3 & 12.1 & 4.0 & 11.6 & 20.6 & & 35.8 \\
\hline 2015 & 0,760 & 12.4 & 12.2 & 3.7 & 11.7 & 21.1 & & 36 \\
\hline
\end{tabular}




\section{Studies in Business and Economics no. 15(3)/2020}

\begin{tabular}{|l|l|l|l|l|l|l|l|l|}
\hline 2016 & 0,751 & 13.2 & 12.9 & 3.5 & 14.2 & 21.0 & & 35 \\
\cline { 1 - 6 } \cline { 5 - 7 } \\
\hline 2017 & 0,753 & 13.5 & 13.1 & 3.5 & 13.1 & 22.8 & & 34.4 \\
\hline 2018 & 0,766 & 12.2 & 11.9 & 3.5 & 12.8 & 19.5 & - \\
\hline
\end{tabular}

Source: (UNDP, 2019d and World Bank, 2019d)

As shown by the analysis of Table 12, in the case of the IHDI performance is lower, as compared with the HDI that was discussed in Table 11. The main source of inequality, as shown in Table 12, is inequality in income. We can also see an increase of inequality in education, from 5.8 in 2010 to 12.8 in 2018. The average loss due to inequality for countries with very high human development stands at 10.7 , and for OECD countries stands at 11.7. In all the years under review, the overall loss for Greece due to inequality exceeds $10 \%$, while the country's performance falls short of that of the very high human development group (UNDP, 2019c). Moreover, the average value of the Gini index for the period 2010-2017 stands at 36.0 and is higher (thus implying higher inequality) than that of Belgium (27.7) and Portugal (35.5).

Table 13. Human Development Index - USA

\begin{tabular}{|c|c|c|c|c|c|}
\hline Years & $\begin{array}{c}\text { Life expectancy at } \\
\text { birth (years) }\end{array}$ & $\begin{array}{c}\text { Expected } \\
\text { years of } \\
\text { schooling } \\
\text { (years) }\end{array}$ & $\begin{array}{c}\text { Mean } \\
\text { years of } \\
\text { schooling } \\
\text { (years) }\end{array}$ & $\begin{array}{c}\text { Gross } \\
\text { national } \\
\text { income } \\
\text { (GNI) } \\
\text { per } \\
\text { capita } \\
\text { (2011 } \\
\text { PPP \$) }\end{array}$ & $\begin{array}{c}\text { Human } \\
\text { Development } \\
\text { Index (HDI) }\end{array}$ \\
\hline 2009 & 78.5 & 16.1 & 13.2 & 49292 & 0,908 \\
\hline 2010 & 78.7 & 16.2 & 13.3 & 50297 & 0,911 \\
\hline 2011 & 78.8 & 16.3 & 13.4 & 50813 & 0,914 \\
\hline 2012 & 78.9 & 16.3 & 13.4 & 51533 & 0,916 \\
\hline 2013 & 78.9 & 16.1 & 13.3 & 52092 & 0,914 \\
\hline 2014 & 78.9 & 16.1 & 13.3 & 52982 & 0,915 \\
\hline 2015 & 78.9 & 16.2 & 13.3 & 54039 & 0,917 \\
\hline 2016 & 78.9 & 16.3 & 13.4 & 54443 & 0,919 \\
\hline 2017 & 78.9 & 16.3 & 13.4 & 55351 & 0,919 \\
\hline 2018 & 78.9 & 16.3 & 13.4 & 56140 & 0,920 \\
\hline 2019 & - & - & - & - & - \\
\hline
\end{tabular}

Source: (UNDP, 2019e)

The study of Table 13 reveals the United States' HDI performance for the period under review. Initially, HDI performance seems to improve, from 0,908 in 2009 to 0,920 in 2018. Moreover, there has been a steady improvement in life expectancy at birth. The increase in the expected years of schooling, and mean years of schooling is minimal during the years under review. Following the onset of the global economic crisis the GNI decreased in 2009, from 51,048 US dollars in 51,048, but in 2019 it rose to the highest level of the period under review, at 56,140 US dollars. The United States' HDI performance for the year 2018 stands at 0,920, higher than the average for the very high human development group $(0,892)$, and also higher than the average for OECD countries $(0,895)$ (UNDP, 2019c). 
Figure 8. Trends in United States' HDI component indices 1990-2018

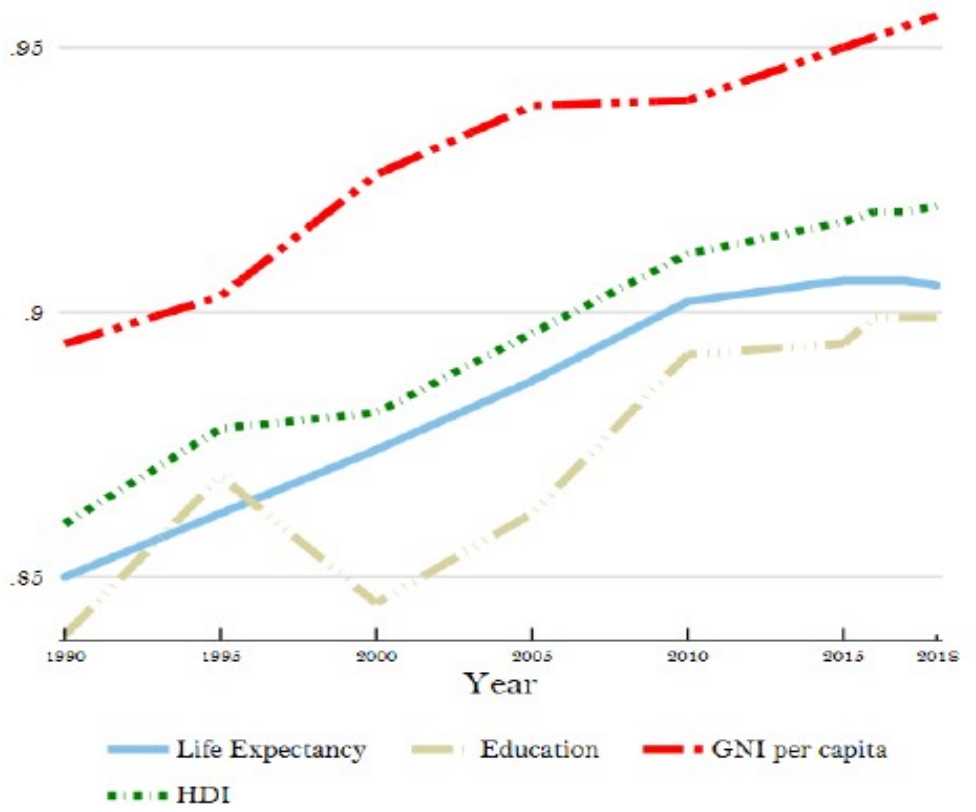

Source: (UNDP, 2019e)

The study of the HDI components, as shown in Figure 8, demonstrates that education shows the worst performance and fluctuated over time, as compared to the other components of the index. Moreover, the GNI component shows the highest HDI performance, since it is much higher than the HDI itself. Finally, the life expectancy component has been steadily improving, moving almost in parallel with HDI performance.

Table 14. Inequality-adjusted Human Development Index (IHDI) - USA

\begin{tabular}{|c|c|c|c|c|c|c|c|c|}
\hline Years & $\begin{array}{l}\text { Inequality- } \\
\text { adjusted } \\
\text { HDI (IHDI) }\end{array}$ & $\begin{array}{c}\text { Overall loss } \\
\text { in HDI due to } \\
\text { inequality } \\
(\%)\end{array}$ & $\begin{array}{c}\text { Coefficient of } \\
\text { human } \\
\text { inequality } \\
(\%)\end{array}$ & $\begin{array}{l}\text { Inequality in } \\
\text { life } \\
\text { expectancy } \\
(\%)\end{array}$ & $\begin{array}{c}\text { Inequality } \\
\text { in } \\
\text { education } \\
(\%)\end{array}$ & $\begin{array}{l}\text { Inequality } \\
\text { in income } \\
(\%)\end{array}$ & $\begin{array}{c}\text { Income } \\
\text { inequality, } \\
\text { Gini } \\
\text { coefficient } \\
2010-2017\end{array}$ & $\begin{array}{c}\text { GINI } \\
\text { index* }\end{array}$ \\
\hline 2009 & - & - & - & - & - & - & \multirow{9}{*}{41.5} & - \\
\hline 2010 & 0,808 & 11.4 & 10.9 & 6.0 & 3.2 & 23.5 & & 40.3 \\
\hline 2011 & 0,774 & 15.3 & 14.2 & 6.6 & 3.7 & 32.4 & & - \\
\hline 2012 & 0,802 & 12.4 & 12.0 & 6.6 & 5.3 & 24.1 & & - \\
\hline 2013 & 0,755 & 17.4 & 16.2 & 6.2 & 6.7 & 35.6 & & 41 \\
\hline 2014 & 0,759 & 17.0 & 15.7 & 6.2 & 5.3 & 35.6 & & - \\
\hline 2015 & 0,793 & 13.5 & 12.9 & 6.1 & 5.6 & 27.0 & & - \\
\hline 2016 & 0,796 & 13.3 & 12.7 & 5.6 & 5.6 & 27.0 & & 41.4 \\
\hline 2017 & 0,793 & 13.8 & 13.1 & 5.6 & 5.5 & 28.1 & & - \\
\hline 2018 & 0,797 & 13.4 & 12.8 & 6.3 & 5.5 & 26.6 & & - \\
\hline 2019 & - & - & - & - & - & - & & - \\
\hline
\end{tabular}

Source: (UNDP, 2019e and World Bank, 2019d)

As shown by the analysis of Table 14, in the case of the IHDI performance is lower, as compared with the HDI that was discussed in Table 13. Inequality in income is the main source of inequality, as shown in Table 14, and is higher in the US as compared to Germany and Greece. We can also see an increase of inequality in education, from 3.2 in 2010 to 5.5 in 2018 . The average loss due to inequality for countries with very high human development stands at 10.7, and for OECD countries stands at 11.7. In all the 
years under review, the overall loss for the US due to inequality is more than $10 \%$, while the country's performance falls short of that of the very high human development group (UNDP, 2019e). Moreover, the average value of the Gini index for the period 2010-2017 stands at 41.5 and is higher, therefore implies higher inequality, than that of Australia (35.8) and Canada (34.0).

Next, we discuss certain economic inequality criteria to demonstrate whether the distribution of income in recent years is a consequence of the process of economic globalisation. Table 15 presents the findings as regards the share of the top $1 \%$ in terms of pre-tax income in total income for the period under review (2009-2017). As shown by the analysis of the data, in China the top $1 \%$ in terms of pre-tax income controlled $15 \%$ of total income in 2009 , this percentage was gradually reduced to $13.9 \%$ of total income, and seems to be positively correlated with the country's GINI index performance, which shows that inequality is reduced, as shown by the data of Table 8 . The analysis of the data for Germany shows that the share of the top $1 \%$ of income earners rose from $11 \%$ in 2009 to $12.5 \%$ in 2017 . The increased inequality of income distribution in Germany seems to lead to an increase in economic inequality, as shown by the GINI index data of Table 10. In Greece, and during the first years of the period under review, the situation is different, as the top $1 \%$ in terms of income commanded $8 \%$ of the total. Gradually, however, the share of the top $1 \%$ increased, reaching $13 \%$ in 2017 . We can see that uneven distribution within the country increased as a result of the outbreak of the Greek sovereign debt crisis, which resulted from the global economic crisis (Roukanas, 2016). The data of Table 12 concerning the GINI index in Greece, show that economic inequality increased since 2009, albeit not as fast as the incomes of the top 1\%, In the US, the income share of the top $1 \%$ is much larger, as in 2009 it stood at $18.5 \%$ and in 2014 it had grown to $20 \%$. This is the highest rate of inequality compared to the other countries under review, also pointing to a correlation with the high percentage of economic inequality in the US, as shown by the GINI index in Table 14. Moreover, we can see that the performance of the US moves almost in parallel with the global average, and it is established that the performance of the other three countries points to lower levels of economic inequality.

Table 15. Pre-tax national income TOP $1 \%$ SHARE

\begin{tabular}{|c|c|c|c|c|c|}
\hline Years & $\begin{array}{c}\text { Pre-tax } \\
\text { national } \\
\text { income share } \\
\text { China }\end{array}$ & $\begin{array}{c}\text { Pre-tax } \\
\text { national } \\
\text { income share } \\
\text { Germany }\end{array}$ & $\begin{array}{c}\text { Pre-tax } \\
\text { national } \\
\text { income share } \\
\text { Greece }\end{array}$ & $\begin{array}{c}\text { Pre-tax national } \\
\text { income share } \\
\text { USA }\end{array}$ & $\begin{array}{c}\text { Pre-tax national } \\
\text { income share } \\
\text { World }\end{array}$ \\
\hline 2009 & 0.1541 & 0.1160 & 0.0846 & 0.1854 & 0.2077 \\
\hline 2010 & 0.1512 & 0.1195 & 0.0882 & 0.1980 & 0.2079 \\
\hline 2011 & 0.1459 & 0.1210 & 0.0736 & 0.1960 & 0.2090 \\
\hline 2012 & 0.1375 & 0.1241 & 0.0788 & 0.2078 & 0.2066 \\
\hline 2013 & 0.1381 & 0.1223 & 0.1038 & 0.1959 & 0.2055 \\
\hline 2014 & 0.1366 & 0.1231 & 0.1291 & 0.2020 & 0.2051 \\
\hline 2015 & 0.1392 & 0.1248 & 0.1367 & - & 0.2056 \\
\hline 2016 & - & 0.1254 & 0.1317 & - & 0.2044 \\
\hline 2017 & - & 0.1254 & 0.1337 & - & - \\
\hline 2018 & - & - & - & - & - \\
\hline 2019 & & - & - & & - \\
\hline
\end{tabular}

Source: (World Inequality Database, 2020a) 
In order to obtain a better understanding of economic inequality, we used the World Inequality Database to examine the long-term trends in country performance regarding the bottom $50 \%$ of income-earners as compared to the top $10 \%$, as shown on Figures $9,10,11$, and 12 . It should be noted that the data for China and the US represent pre-tax income, whereas those for Germany and Greece represent post-tax income. The data available for each country vary, as we can see that, in the case of the US, the data refer to a much longer time period, as they extend from 1913 to 2014. In the case of China, it seems that the long-term trend points to an increase of economic inequality between the top $10 \%$ and the bottom $50 \%$ since 1970 , and a further increase since the 2000 s.

Figure 9. Income inequality, China, 1978-2015

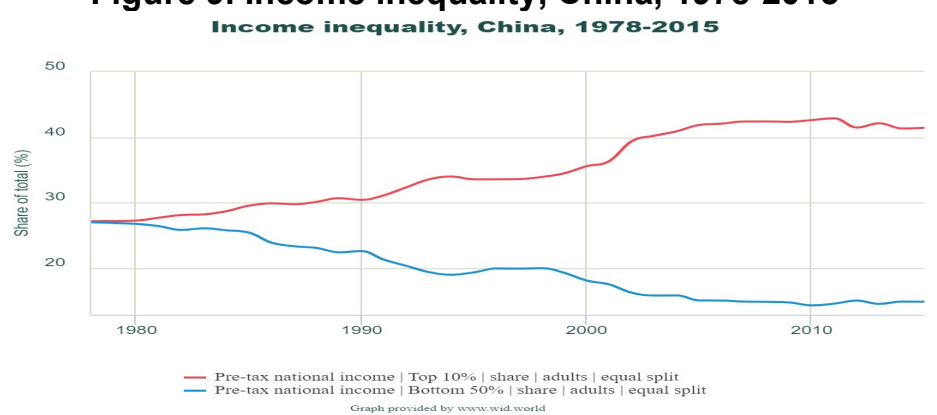

Source: (World Inequality Database, 2020b)

The analysis of the data for Germany refers to post-tax income and shows that from 1980 to 2000 the bottom $50 \%$ of income earners commanded a larger share than the top $10 \%$. Gradually, and in particular after 2010 , there has been an increase in the income of the top $10 \%$ compared to the bottom $50 \%$, and we can see that the increase in income inequality became more pronounced in the 2010s. In Greece, the unequal distribution of income between the two groups under review remained more or less stable, as from 1980 to 2016 the top $10 \%$ commanded a share of post-tax income that in most years stood above $30 \%$, while the share of the bottom $50 \%$ stood at less than $20 \%$. In the US, we can see that the share of the bottom $50 \%$ in pre-tax income stands at about $20 \%$ over time, whereas after the onset of the global economic crisis of 2007-2008 this percentage has been further reduced. In contrast, the share of the top $10 \%$ in pre-tax income after World War II declined and remained below $40 \%$, but since the 1980 s, and especially after the onset of the global economic crisis, this percentage gradually rose to almost $50 \%$.

Figure 10. Income inequality, Germany, 1980 - 2016

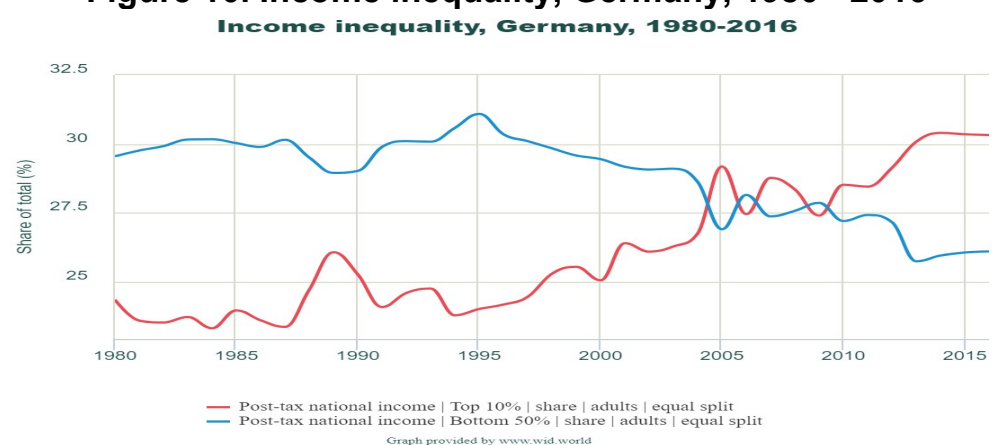

Source: (World Inequality Database, 2020c) 
Figure 11. Income inequality, Greece, 1980 - 2016

Income inequality, Greece, 1980-2016

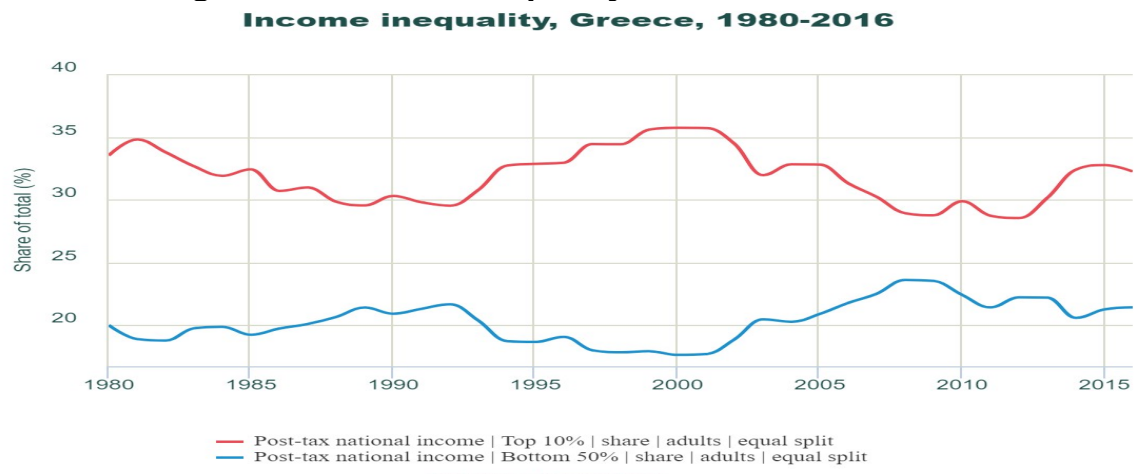

Source: (World Inequality Database, 2020d)

Figure 12. Income inequality, USA, 1913 - 2014

Income inequality, USA, 1913-2014

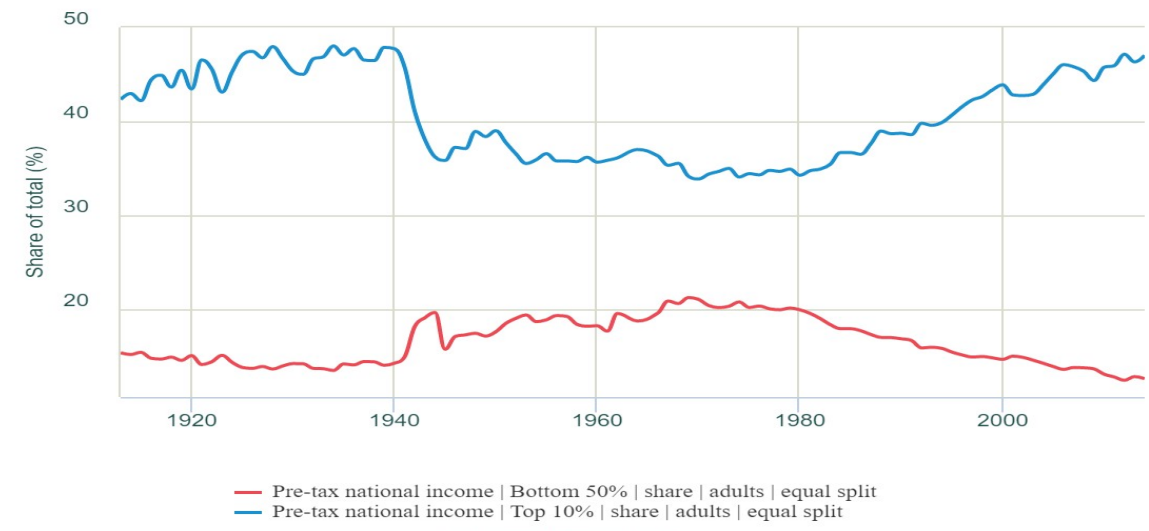

Source: (World Inequality Database, 2020e)

The Organisation for Economic Cooperation and Development (OECD), in a recent report that was published in 2019, titled: Under Pressure: The Squeezed Middle Class, highlights the issue of increased inequality during the last 30 years, emphasising on the concept of the middle class. The OECD points to the deterioration or stagnation of economic prospects in many of its member states, while at the same moment top income groups have increased their share. According to the OECD report, the generations that came after the so-called "baby boomers" (people born 1943-1964) are less likely to belong to the middle class. As shown in Figure 13, all generations following the baby boomers show lower shares of population that belong to the middle class in all stages of their life cycle. Moreover, it is important to stress that the percentage of those who belong to the middle class is further reduced with each generation. 
Figure 13. Share of population in middle-income households by generation and stage at the life cycle

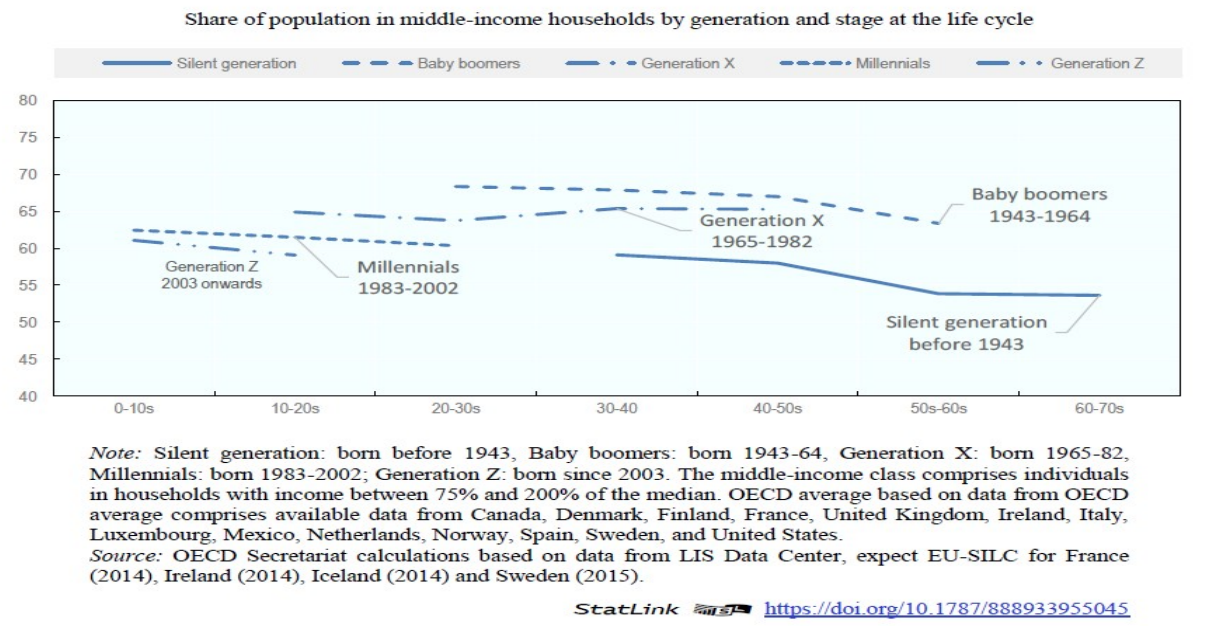

Source: (OECD, 2019, p. 26)

As shown by the analysis of Figure 13, defining the concept of the middle class is crucial for the fuller understanding of the concept of economic inequality. The OECD attempts to define the concept of middle income based on per capita GDP, pointing to different levels for each country. It calculates the income for the year 2016 or the latest available income for one-member households in 2010 US dollars, based on purchasing power parity. It is important to stress that the middle-income class includes persons living in households with incomes ranging from $75 \%$ to $200 \%$ of the median income (OECD, 2019, p. 45). Table 16 shows income levels for the countries under review, and includes both the lower and upper thresholds. As shown by the data of Table 16, there is a discrepancy among the countries under review as regards the definition of middle income. At the same time, there seems to be a strong discrepancy between the lower and the upper threshold for each country. It is obvious that there is a great discrepancy as regards the definition of economic inequalities and the prospects of the middle class from country to country.

Table 16. Middle-income thresholds in OECD countries and selected emerging economies*

\begin{tabular}{|c|c|c|}
\hline Countries & Lower threshold & Upper threshold \\
\hline China & 4862. & 12967. \\
\hline Germany & 17861. & 47628. \\
\hline Greece & 7894. & 21050. \\
\hline United States & 23416. & 62442. \\
\hline
\end{tabular}

* 2016 or latest available year, adjusted for one-person households and in US PPP for 2010

Source: (OECD, 2019, p. 45)

\section{Conclusions}

The study of the indices used for measuring economic development and the process of economic globalisation reveals their effects on economic inequality. First, we discussed the IMF's Financial Development Index, as well as trade openness and its 
correlation with per capita GDP. We saw that the US show a high degree of financial development, followed by the other countries, in this order: Germany, China, and Greece. Trade openness was higher in the case of Germany, followed by Greece, China, and the US. We saw that there is no positive correlation between trade openness and the growth of per capita GDP. Then we discussed the Human Development Index and its variables, the study of which is focused on the concepts of development and inequality. We saw that Germany is the best performer, followed by the US and Greece, while China is ranked last, as a developing economy. Moreover, we studied economic inequality criteria for determining the income distribution in the countries under review. We can see that economic globalisation has, by means of the liberalisation of the financial system and the opening of trade, improved the countries' performance as regards the Human Development Index, but at the same time economic inequalities within the countries under review are either entrenched or increasing. This new reality poses a challenge for economic policy-makers, for the following reasons: 1) increased economic volatility and more frequent manifestation of economic crises as a consequence of financial liberalisation; 2) stagnant economic growth in developed and rapidly developing countries, as the middle class will not be able to make a substantial contribution to the consumption of goods and services because of income limitations; 3) reduced economic development prospects, as increasingly smaller sections of the population will have adequate resources in order to access education and health, which are crucial for increasing the added value of the goods and services that the countries produce and export. In conclusion, economic inequalities give rise to a self-reinforcing vicious spiral of economic stagnation, recession, and limited economic development, undermining the prospects of the global economy. It is imperative to take initiatives that will turn this vicious spiral into a virtuous circle of economic growth, development, and reduced economic inequalities, as any delay in implementing the necessary economic reforms will impose a higher economic and fiscal cost on the countries under review.

\section{Acknowledgement}

This work has been partly supported by the University of Piraeus Research Centre.

The present study has been presented at the 12th International Conference "Economies of the Balkan and Eastern European Countries", EBEEC 2020, that has been held online in Opatija, Croatia from May 29th to 31th 2020 (http://ebeec.ihu.gr/).

\section{References}

Dabla-Norris, E. Kochhar, K., Ricka, F., Suphaphiphat, N. and Tsounta, E. (2015), Causes and Consequences of Income Inequality: A Global Perspective, IMF Staff Discussion Note, June 2015, SDN/15/13.

IMF (2019a), World Economic Outlook (April 2020), 25-04-2020, available online at https://www.imf.org/external/datamapper/datasets/WEO

IMF (2019b), Financial Development Index Database, 25-04-2020, available online at https://data.imf.org/?sk=F8032E80-B36C-43B1-AC26-493C5B1CD33B 
IMF (2019c), Financial Development Index Database, 25-04-2020, available online at https://data.imf.org/?sk=F8032E80-B36C-43B1-AC26-493C5B1CD33B\&sld=1480712464593

IMF (2019d), Financial Development Index Database, 25-04-2020, available online at https://data.imf.org/?sk=F8032E80-B36C-43B1-AC26-493C5B1CD33B\&sld=1481207801912

IMF (2019e), Financial Development Index Database, 25-04-2020, available online at https://data.imf.org/?sk=F8032E80-B36C-43B1-AC26-493C5B1CD33B\&sld=1481126573525

International Monetary Fund, The World Bank kaı World Trade Organization (2017), Making Trade an Engine of Growth for All: The Case for Trade and for Policies to Facilitate Adjustment, International Monetary Fund, The World Bank kaı World Trade Organization.

McGrew, A. (2017), The Logics of Economic Globalization, in John Ravenhill (ed.), Global Political Economy, Oxford, Oxford University Press, pp. 255-315.

OECD (2019), Under Pressure: The Squeezed Middle Class, OECD Publishing, Paris. available online at https://doi.org/10.1787/689afed1-en

Ostry, Loungani and Furceri, (2016), Neoliberalism: Oversold?, FINANCE \& DEVELOPMENT, June 2016, Vol. 53, No. 2, available online at https://www.imf.org/external/pubs/ft/fandd/2016/06/ostry.htm

Ravenhill, J. (2017a), Global Political Economy, Oxford, Oxford University Press.

Ravenhill, J. (2017b), The study of Global Political Economy, in John Ravenhill (ed.), Global Political Economy, Oxford, Oxford University Press, pp. 3-25.

Roukanas, S. (2016), The Political Economy of the Greek Crisis: 2010-2015, in Spyros A. Roukanas and Pantelis G. Sklias (eds.), The Greek Political Economy 2000-2015, Delft, Eburon, pp. 429-445.

Salvatore, D. (2017), International Economics (in Greek), $12^{\text {th }}$, Thessaloniki, Tziola Publications.

UNDP, (2018a), Human Development Indices and Indicators 2018 Statistical Update, New York, UNDP.

UNDP, (2018b), Technical notes: Calculating the human development indices-graphical presentation, New York, UNDP.

UNDP, (2019a), China: Human Development Indicators, 26-04-2020, available online at http://hdr.undp.org/en/countries/profiles/CHN

UNDP, (2019b), Inequality-adjusted Human Development Index (IHDI), 27-04-2020, available online at http://hdr.undp.org/en/content/inequality-adjusted-human-development-index-ihdi

UNDP, (2019c), Germany: Human Development Indicators, 27-04-2020, available online at http://hdr.undp.org/en/countries/profiles/DEU\#

UNDP, (2019d), Greece: Human Development Indicators, 27-04-2020, available online at http://hdr.undp.org/en/countries/profiles/GRC

UNDP, (2019e), United States: Human Development Indicators, 27-04-2020, available online at http://hdr.undp.org/en/countries/profiles/USA

World Bank, (2020), About WITS , 27-04-2020,__available online at http://wits.worldbank.org/WITS/WITS/TradelndicatorsHelp/TradeOutcomes Help.htm\#OtT

World Bank, (2019a), GDP (current US\$), 25-04-2020, available online at https://data.worldbank.org/indicator/ny.gdp.mktp.cd?most recent value desc=true \&view=ma $\underline{p}$

World Bank, (2019b), Trade (\% of GDP) - China, Germany, Greece, United States, 27-04-2020, available online at https://data. worldbank.org/indicator/NE.TRD.GNFS.ZS?end=2018\&locations=CN-DE-GRUS\&start=2009

World Bank, (2019c), GDP per capita (current US\$) - China, Germany, Greece, United States, 2704-2020, available online at 
https://data. worldbank.org/indicator/NY.GDP.PCAP.CD?end=2018\&locations=CN-DE-GRUS\&most recent value desc=true\&start=2009

World Bank, (2019d), GINI index (World Bank estimate), 26-04-2020, available online at https://data. worldbank.org/indicator/SI.POV.GINI?end=2017\&locations=CN-DE-GR$\underline{\text { US\&start }=2009}$

World Inequality Database, (2020a), Pre-tax national income TOP 1\% SHARE, 02-05-2020, available online

https://wid.world/data/\#countriestimeseries/sptinc p99p100 z/US;FR;DE;CN;ZA;GB;WO/193 0/2018/eu/k/p/yearly/s

World Inequality Database, (2020b), Income inequality, China, 1978-2015, 02-05-2020, available online at https://wid.world/country/china/

World Inequality Database, (2020c), Income inequality, Germany, 1980-2016, 02-05-2020, available online at https://wid.world/country/germany/

World Inequality Database, (2020d), Income inequality, Greece, 1980-2016, 02-05-2020, available online at https://wid.world/country/greece/

World Inequality Database, (2020e), Income inequality, USA, 1913-2014, 02-05-2020, available online at https://wid.world/country/usa/ 